\title{
A PREFACE TO A THEORY OF ART-FEAR IN BRAZILIAN LITERATURE
}

Julio França

Universidade Estadual do Rio de Janeiro

Luciano Cabral da Silva

Universidade Estadual do Rio de Janeiro

\begin{abstract}
There is no tradition in the study of horror in Brazilian literature; with Álvares de Azevedo"s tales of Noite na Taverna generally considered as the only example of Gothic, terror or horror narrative quoted in literary history. This article aims to demonstrate that there are several works in Brazilian literature which could be classified as "fear literature" - a fictional narrative that produces "artistic fear". In fact, some of the most important Brazilian authors, including Machado de Assis, Bernardo Guimarães, Aluísio Azevedo, Inglês de Souza, João do Rio, Humberto de Campos and Coelho Neto, penned works in the macabre during the nineteenth and early twentieth centuries. However, critics were either unable to identify them as works of horror or paid no attention to an area of fiction in which social problems were not realistically represented. Therefore, research in this field must first identify the basic characteristics
\end{abstract}

\begin{tabular}{|l|l|l|l|l|}
\hline Ilha do Desterro & Florianópolis & $n^{\circ} 62$ & p. 341- 356 & jan/jun 2012 \\
\hline
\end{tabular}


342 Julio França e Luciano Cabral da Silva, A preface to a Theory of Art...

of fictional horror in our country. We are interested in (i) the real fears represented in Brazilian fiction, be them caused by either the natural or supernatural, and in (ii) the narrative features which produce the effect of "artistic fear" upon the reader.

Keywords: Horror literature, Terror, Fear literature, Brazilian Literature, Artistic fear.

\section{Introduction}

Our current conception of the world is of it being an extremely dangerous place in which to live. Despite having provided an unprecedented level of safety in people"s lives, science and its achievements still haven"t been able to depose fear from the position of one of the most restless and intense feelings experienced by human beings.

As an inherent part of human nature, fear is closely connected to mechanisms of protection. This instinctive relationship means the experience of fear is frequently accompanied by an awareness of our mortality. The mystery of death-unavoidable and incomprehensible - is at the core of narratives which deal with this side of existence, about which science has little to say. In the gap between religious belief and scientific knowledge, the so-called narratives of fear are ideally situated. The ever-present and unstoppable fear of our final destiny is what makes fear both universal and appealing.

When in danger, the emotions related to our struggle for survival are painful. Nonetheless, when we experience such emotions without being at risk, i.e., when the reasons for being afraid do not represent a real threat to those who experience it, we are surely dealing with an aesthetic pleasure. This is the belief upon which our current research, "Fear as an aesthetic pleasure", has been developed. We are interested 
in studying (i) the literary representation of real fears throughout history, (ii) the literary process of creating artistic fears, and also in (iii) trying to understand the reasons why readers are attracted by fictional horror in a world full of real horror.

In order to clarify some methodological and conceptual paths we have trodden, some aspects of our research are worth discussing.

First of all, it seems necessary to explain the reasons why we have named our ambit "fear literature" instead of adopting a more conventional and precise term such as "horror", "terror", or even "gothic". When we started studying the manifestations of horror in Brazilian literature, we noticed that national critical studies on the theme were dramatically rare. It was then clear to us we would have to base our theoretical research on other literary traditions. As a starting point, we opted to collect a theoretical corpus which included critical analyses written by authors usually labeled as horror writers, so as to have their own thoughts on what is undoubtedly one of the greatest paradoxes in Horror Literature: "Why do you want to make up horrible things where there is so much real horror in the world?" (King 16).

We finally selected five well-known authors who have left important analyses on the subject of horror fiction: Horace Walpole, Mary Shelley, Edgar Allan Poe, Howard Phillips Lovecraft, and Stephen King. It became evident that exploring the reader"s sense of fear is highly crucial to these writers. Moreover, we also concluded that they adhere to two philosophical standpoints: (i) Aristotle"s understanding and defense of art not only for its cognitive, but also for its sensitive aspects, and (ii) Edmund Burke"s promotion of the affection of fear and horror as the main sources for an intense and unique aesthetic experience, namely the sublime. 


\section{Fear as an aesthetic pleasure}

Narratives which can produce fear in readers have been constantly written and, not surprisingly, there is in fact a myriad of essential terms in the Literary Studies somehow connected to them, such as catharsis, sublime, and grotesque. Although both fear and the stories which produce it are primeval, the relationship between this emotion and literature is surely in close touch with the contemporary world.

Our realization originates from Jean Delumeau and Zigmunt Bauman, both of whom claim that science has provided a level of safety from harm never reached before. Paradoxically, our primitive and often irrational fear is still one of the strongest feelings that we experience. Hence, we started to refer to such narratives as Fear Literature, a provisional term that intends to deal with two different features:

i. the way real fears are literarily represented;

ii. the way fictional fears are constructed.

As a consequence, we felt obliged to widen our scope. Horror literature has traditionally relied upon supernatural stories as a typical way of representing the fear of the unknown through the use of monsters (creatures which science cannot conceive). Our conception of fear literature, on the other hand, is not exclusively oriented by monsters or fantastic elements, since Brazilian literature seems to be grounded in other ways of inciting fear.

In fact, there are three main sources of human suffering, and consequently of human fear, listed by Sigmund Freud (93) in "Civilizations and its discontents": (i) our body, unavoidably fated 
to decay and dissolution; (ii) nature itself, which can destructively and mercilessly turn against us; and also (iii) human behavior, unpredictable, and as such, frightening. It does not matter how varied or random the source, whether caused by the natural or supernatural, or how unknown that which produces the emotion of fear is-there is always an idea which unifies them all: death.

According to Edmund Burke, the supremacy of the passions connected to our struggle for survival relates to the fact that we should obviously be healthy and alive to do whatever we intend to. If an event is seen as a threat to our health and life, it affects us more seriously than any other. Therefore, we have reached the idea of art-fear. As the passions connected to death and pain are the most intense ones to men, it is exactly when we experience these same emotions in a threatening situation of a fictional nature that we may better experience the sublime. Feeling pain or danger while not really at risk would be capable of producing a feeling of relief, or delight-a specific type of pleasure, albeit not a positive one as it is caused by pain.

Being equally intenseand primeval, the awareness of our mortality places us far removed from other animals. Many philosophers have tried hard to demonstrate that the fear of death is unreasonableafter all, we can only feel it as "second-level" emotion. In other words, we are able to experience our own pain or sorrow, but we can never experience our own death. We may grieve for someone who has died, but we cannot do so if we die. A person and their death are never together, the latter implies the absence of the former.

On the other hand, imagination provides us the capacity to picture ourselves dead, deprived from our will to live eternally. As Francis Wolff (37) puts it, in the fear of death we imaginarily double 
ourselves. There is the one I am right now-the one who feels fear, who is alive - and the one I imagine dead. It is the image of my "dead self" that frightens me, for we suffer as we imagine ourselves dead.

Fear produced by imagination is similar to that of the fiction mechanisms binding readers and characters. The movement which guides us to feel our most primeval, universal and intense fear-the fear of death-literarily corresponds to the one which makes us experience fear while we are surely out of danger. We name such an experience as art-fear.

\section{Fear literature in Brazil}

At this stage, we are in a position to reflect on art-fear in regard to Brazilian literature. Some potential analytical paths open ahead of us:

- Analyzing historical and geographical variations of the cultural representation of fear in Brazilian literature;

- Describing textual techniques and elements responsible for the production of so-called art-fear, by means of analytical reading of fictional works belonging to this genre;

- Developing a concise critical history of art-fear in Brazilian literature by means of building a corpus of thematically representative literary works;

- Creating an outline of a possible history of the fears in our society by means of literary representations. 
For any of these primary analytical paths, the first challenge would be setting a corpus of Brazilian literary works that would be able to withstand a reading perspective whose focus should be on the fear raised as an effect of reception. But what would these works be? After all, if an expert on canonical Brazilian literature were to be asked, it is likely that our hypothetical interlocutor would mention Noite na Taverna, by Álvares de Azevedo. Taking for granted the merit of knowing how appropriate this classification is, what would happen if he were asked to provide a second example? We might assume that our interlocutor would hesitate.

Would the difficulty to list examples also occur in relation to other genres or themes? Let"s say we asked our hypothetical expert for examples of works on love, war, childhood, Brazilian natives, identity, politics, economy or religion, among others. Would he find this task as difficult as the one assigned to him earlier? What if examples of horror narratives in non-Brazilian literature were to be requested, would his hesitation continue? It is quite unlikely.

To what conjectures did these supposed empirical observations take us? The first hypothesis lies on the fact that, when it comes to Brazilian literary historiography, there is nothing that could be called horror narrative other than Noite na Taverna. In order to counter such hypothesis, a simple methodological procedure was adopted. We searched through national literary anthologies, ${ }^{1}$ whose titles would include words such as horror, terror, evil, cruel, violent, and fantastic. The last revealed itself to be a fundamental methodological assertion, as what should be called fear literature in the tradition of Brazilian criticism has always been intimately thought of as being related to the Fantastic genre.

Thus, we were able to build an initial corpus, ${ }^{2}$ which in spite of not being very extensive, demonstrated the variety of themes, 
authors and literary styles that somehow embody fear as an element of the narrative-being an element of the plot, and/or an effect of reception produced on readers.

Such a conclusion led us to a second hypothesis that there are indeed narratives in the ambit of Brazilian literature which could be classified as fear literature. These, however, had not been considered noteworthy due to an absence of a formal reception. How could this absence be explained? As far as we are concerned, there is no simple answer to this question, but rather a maze of causes and factors to be taken into consideration.

First of all, literary history and criticism in Brazil have evidently focused on more realistic themes, especially those explicitly related to issues of national identity. In his important doctorate thesis entitled $A$ obstrução ao fantástico como proscrição da incerteza na literatura brasileira [The obstacle to the fantastic as a proscription of uncertainty in Brazilian literature], Murilo Garcia Gabrielli pointed out the way in which Brazilian literature, from romanticism through realism, had been taken over by the project of building a national identity, which consequently restrained any other theme considered unsuitable for such a purpose.

Such an expectation of art demands of our literature an explicit and continuous reflection on the issues of a Brazilian "reality". Such demands are so powerful that they turn the expectation into an aesthetic value, even nowadays. As an example, we quote part of Roberto de Souza Causo"s comment on Noite na Taverna and Macário:

Álvares de Azevedo [...] [escolheu] personagens e ambiência alienígenas ao contexto social brasileiro de sua época. Mais que isso, sua narrativa foi enfraquecida pelos índices imitativos nela presentes, que remetem não só a outra realidade, mas a outro 
ideário não dominado pelo autor, tornando-o apenas um imitador das convenções góticas. ${ }^{3}$ (108)

[...] a carência da cor local (tanto brasileira quanto estrangeira, pois o vago da ambiência torna-se cada vez mais incômodo à medida que caminha a narrativa) é um fato a apontar para uma postura detectável de negação da realidade brasileira, e de qualquer intenção de agir sobre ela [...]. ${ }^{4}(109)$

Identifying a work of fear literature in Brazil implies not only the disclosure of narratives and writers forgotten by hegemonic criticism, but also a re-reading, from a different perspective, of Brazilian fiction, including authors and works which have already been recognized by the literary tradition. In Literary Studies, facts are only so when they are objects of analysis; i.e. they only become clear when described by us.

A second crucial factor for the obliteration of fear literature in Brazil could be related to the inexistence of a systematic national production of the genre. There are at least three causes for this inexistence: (i) the absence of a specific literary movement such as Gothic romanticism, (ii) the absence of an emblematic author dedicated almost entirely to the genre, such as Edgar Allan Poe, and (iii) the great offer of fear literature translated into Portuguese. ${ }^{5}$ These factors were all influential in preventing the development of an explicit system of production and consumption of Brazilian fear literature. ${ }^{6}$ These drawbacks may also have triggered critics to not take fear literature seriously.

Furthermore, a tradition of fear literature in Brazil is unnoticed. This might be because many of the works that would fit this category "might not have been produced in this key" (Causo 34)—Brazilian fear literature authors have never seen themselves as writing for such a genre. We should track down-by means of an almost archaeological procedure- 
the presence of themes, motifs, plots, characters, and ambiences in order to uncover the hidden tradition of fear within our literature.

Lastly, a third factor may be related to the lack of eagerness critics had for popular literature. Questioning the aesthetic quality of a piece of work is a recurrent action taken by Literary Studies to justify their indifference concerning popular narratives. For decades, they have been doing so.

From a meta-critical perspective, we could openly state that unstable and dubious personal taste should never rule or delineate any analysis of research. The matter should be approached first by a more complex process which involves description and interpretation, amongst others, and only then by value judgment-if relevant. In other words, value judgment should not determine what is to be studied or not.

This way, studies such as that of Alessandra El Far on the socalled sensation novels, remind us of how literary works go beyond the set of books and authors that critics and the historiography select as the most significant of a certain period of time.

A história da literatura descartou tais livros e elegeu para o seu campo de estudo um conjunto de obras e autores, que nos dias de hoje passam a impressão de ter atuado de maneira isolada, sequencial e triunfante. Porém, ao lidarmos com o universo das letras é preciso perceber que esse quadro era muito mais complexo e difuso. Além dos romancistas selecionados pela crítica, inúmeros outros atuavam ao mesmo tempo, conseguindo, em muitos casos, difundir seus textos e tendências narrativas com significativo sucesso. [...] a experiência da leitura, no Rio de Janeiro daquele período, em nenhum momento se reduziu aos cânones literários e aos escritores adeptos das belas-letras que atualmente fazem parte dos compêndios literários. Naqueles anos, lia-se Machado de Assis, Aluísio Azevedo, Raul Pompéia, 
mas lia-se também uma variedade de outros escritores que buscavam o sucesso por meio de histórias "arrebatadoras": "cheias de mistério", de "sangue", em certos casos, ousadas em seus beijos e cópulas apaixonadas. (El Far 24-5)

Any research on fear literature in Brazil should not be influenced by the biased judgement of critics. It should, on the contrary, choose a more descriptive position, open to the perception of the multiple forms texts we name as "literature" may have. Only by doing so would we be able to identify the importance of fear in Brazilian fiction.

\section{What would Brazilian fear literature be?}

Gothic literature can undoubtedly be placed in the origins of European and North-American modern fear literature. In Brazil, some research, such as that of Alexander Meirelles Silva, Daniel Serravalle de Sá, and Maurício César Menon, among others, has successfully demonstrated the Gothic influence on nineteenth- and twentieth-century Brazilian writers.

Nevertheless, such studies may not be the only key to identifying our own tradition of fear literature. As we look for influences of European and North American horror literature on Brazilian writers, most of the time we find clichés which have been absorbed. In other words, when one attempts to look for "the same" what is found is "the same". In this current research, we hypothesize that fear literature in Brazil features more realistic themes rather than the supernatural ones commonly found in European and North American narratives.

We do not deny that legends, popular myths, traditional customs and folklore can potentially build up the supernatural themes of our fear literature. However, it seems extremely profitable to consider the core of our horror fiction to be the fear derived from natural causes. 
Many are the factors which may lead to fear literature in Brazil: (i) the threat coming from local nature, qualified by the native and by the European as both magnificent and terrible, full of cataclysms, diseases and wild animals; (ii) affections coming from our mournful existence, from the dreadful awareness of our mortality, of our inevitable death, of our mental and bodily decay; and finally (iii) fears coming from "the other"; the violence and cruelty which are inherent to human beings, which constitute a permanent and yet irrational threat as their behavior is unpredictable.

In a place where horror "has been instituted" (Hansen 17-18), why should we not have horror fiction stories? Reasonably, Stephen King (1983) reminds us that one of the purposes of horror fiction is to teach people how to cope with real fears.

\section{Notes}

1. Check some of these anthologies in the bibliographic references.

2. We could quote "Flor, telefone, moça" (Carlos Drummond de Andrade); "A causa secreta" (Machado de Assis); "Demônios" (Aluísio de Azevedo); "Os olhos que comiam carne" (Humberto de Campos); "Valsa fantástica" (Afonso Celso); "Esfinge" (Coelho Neto); "A cobra preta" (Viriato Correa); "O Espelho" (Gastão Cruls); "Confirmação" (Gonzaga Duque); "Feliz ano novo" (Rubem Fonseca); "Assombramento" (Afonso Arinos de Melo Franco); "A dança dos ossos" (Bernardo Guimarães); "A gargalhada" (Orígenes Lessa); "Bugio Moqueado" (Monteiro Lobato); "O defunto" (Thomaz Lopes); “Um prego, mais outro prego!” (Adelino Magalhães); "O satanás de Iglawaburg" (Adelpho Monjardim); “A menina morta" (Cornélio Penna); "No hospício" (Rocha Pombo); "Paulo" (Graciliano Ramos); "Dentro da noite" (João do Rio); "A podridão viva" (Amândio Sobral); "Acauã” (Inglês de Souza); "Venha ver o pôr do sol" (Lygia Fagundes Telles), among others.

3. "Álvares de Azevedo [...] [chose] characters and ambience alien to the Brazilian social context of his time. Moreover, his narrative was weakened by the imitational levels presented in it, which takes readers 
back, not only to another reality, but to another idea which is not well-known by the author, thus making him a copycat writer of gothic conventions." [Our translation].

4. "[...] the lack of local color (as much Brazilian as foreign, as the vague idea of the ambience becomes more unpleasant as the plot unfolds) is a fact which leads to a detectable posture of denying the Brazilian reality, and any intention of acting upon it. [...]". [Our translation].

5. João Adolfo Hansen (23) has already called attention to the way in which foreign horror literature has always flooded our market, making foreign literary works cheaper than any national production would be.

6. Works such as those of Sandra Guardini Vasconcelos show how the English Gothic romance, different from what was thought for a long time, spread in great number throughout the country in the first half of the nineteenth century. These studies show how Gothic (the first modern fear literature) was not only popular amongst Brazilian readers, but also amongst authors. Daniel Serravalle de Sá, for instance, draws attention to the influence of the Gothic on José de Alencar.

7. "The history of literature has dismissed some books and selected a set of books and authors to compose their field of studies. Nowadays it gives the impression that they had acted sequentially and triumphantly in an isolated fashion. However, when we deal with the world of literature it is necessary to notice that this panorama used to be much more complex and blurred. Many more novelists than the ones selected by critics were writing at the same time, in many cases managing to spread their writings and narrative tendencies quite successfully. [...] the experience of reading in Rio de Janeiro at that time was at no moment limited to literary canons and novelists adherent to the belle lettres which are currently part in literary anthology. At that time, people used to read Machado de Assis, Aluísio de Azevedo, Raul Pompéia, but they also used to read a wide range of other authors that looked for success by means of "thrilling" stories: "full of mystery", of "blood", and in certain cases, "daring in their kisses and passionate coupling." [Our translation]. 


\section{References}

Bauman, Zygmunt. Medo líquido. Rio de Janeiro: Jorge Zahar, 2008.

Burke, Edmund. A philosophical enquiry into the origin of our ideas of the sublime and beautiful. New York: Oxford University Press, 1990.

Carroll, Noël. The philosophy of horror or the paradoxes of heart. Nova York, NY: Routledge, 1990.

Cascudo, Luís da Câmara. Contos tradicionais do Brasil. Belo Horizonte: Itatiaia; São Paulo: EdUSP, 1986.

Causo, Roberto de Souza. Fiç̧ão cientifica, fantasia e horror no Brasil: 1875 a 1950. Belo Horizonte: Editora UFMG, 2003.

Costa, Flávio Moreira da, org. Os melhores contos de medo, horror e morte. Rio de Janeiro: Nova Fronteira, 2005.

Delumeau, Jean. História do medo no Ocidente; 1300-1800. São Paulo: Companhia das Letras, 2001.

Dobránszky, Enid Abreu (ed.). Clássicos do sobrenatural. São Paulo: Iluminuras, 2004.

Elfar, Alessandra. Páginas de sensação: literatura popular e pornográfica no Rio de Janeiro (1870-1924). São Paulo: Companhia das Letras, 2004.

Esteves, Lainister de Oliveira (ed.). Contos macabros; 13 histórias sinistras da literatura brasileira. Rio de Janeiro: Escrita Fina, 2010.

Fernandes, Rinaldo de (ed.). Contos cruéis; as narrativas mais violentas da literatura brasileira contemporânea. São Paulo: Geração Editorial, 2006.

França, Julio. "Fontes e sentidos do medo como prazer estético". In: org. Anais do VII painel reflexões sobre o insólito na narrativa ficcional / I Encontro nacional insólito como questão na narrativa ficcional. Rio de Janeiro: Dialogarts, 2011. Web. 15 Nov. 2011.

. "Fundamentos estéticos da literatura de horror; a influência de Edmund Burke em H. P. Lovecraft". In: Caderno Seminal Digital. No. 14., jul./dez. 2010. Rio de Janeiro: Dialogarts, 2010. Web. 15 Nov. 2011

. "O horror na ficção literária; reflexão sobre o "horrível" como uma categoria estética”. In: NITRINI, Sandra et. al. Anais do XI Congresso 
Internacional da ABRALIC. São Paulo: ABRALIC, 2008. Web. 15 Nov. 2011.

. As relações entre "monstruosidade" e "medo artístico": anotações para uma ontologia dos monstros na narrativa ficcional brasileira. In: RODRIGUEZ, Benito Martinez, org. Anais do XII Congresso Internacional da ABRALIC. Curitiba: ABRALIC, 2011. Web. 15 Nov. 2011.

Freud, Sigmund. “O mal-estar na civilização”. Obras psicológicas completas de Sigmund Freud; edição standard brasileira. V. XXI. Tradução de José Octavio de Aguiar Abreu. Rio de Janeiro: Imago, 1996. 73-148.

Gabrielli, Murilo Garcia. A obstrução ao fantástico como proscrição da incerteza na literatura brasileira. Rio de Janeiro, UERJ, Instituto de Letras, 2004. 157 fl. digitadas. Tese de Doutorado em Literatura Comparada.

Hansen, João Adolfo. "Prefácio”. Ficção cientifica, fantasia e horror no Brasil: 1875 a 1950. Belo Horizonte: Editora UFMG, 2003. 15-23.

King, Stephen. Danse Macabre. New York: Berkley Books, 1983.

Lovecraft, Howard Phillips. Supernatural horror in literature. Introduction by E. F. Bleiler. New York: Dover, 1973.

Menon, Mauricio César. Figurações do gótico e de seus desmembramentos na literatura brasileira; de 1843 a 1932. 2007. Tese (Doutorado em Letras). Faculdade de Letras, Universidade Estadual de Londrina. Londrina, Paraná.

Monteiro, Jerônimo (ed.). O conto fantástico. Rio de Janeiro: Civilização Brasileira, 1959.

Penteado, Jacob (ed.). Obras primas do conto fantástico. São Paulo: Martins, 1961. (ed.). Obras primas do conto de terror. São Paulo: Martins, 1962.

Poe, Edgar Allan. Poems and Essays. London: Dent, New York: Dutt; 1977.

Sá, Daniel Serravalle de. Gótico Tropical; o sublime e o demoníaco em $O$ Guarani. Salvador: EDUFBA, 2010.

Silva, Fernando Correia da, and José Paulo Paes. Maravilhas do conto fantástico. Prefácio de José Paulo Paes. São Paulo: Cultrix, 1960. 
356 Julio França e Luciano Cabral da Silva, A preface to a Theory of Art...

Silveira, Brenno. Antologia de contos de terror e do sobrenatural. Rio de Janeiro: Civilização Brasileira, 1959.

Tavares, Bráulio (ed.). Páginas de sombra; contos fantásticos brasileiros. Rio de Janeiro: Casa da Palavra, 2003.

Vasconcelos, Sandra Gardini. "Leituras Inglesas no Brasil Oitocentista". Crop. FFLCH/USP, São Paulo, n. 8, p. 223-247, 2002.

Wolff, Francis. “Devemos temer a morte?”. Ensaios sobre o medo. Ed. Adauto Novaes (ed.). São Paulo: SENAC SP / SESC SP, 2007. 17-38.

[Received in 15/11/2011. Approved in 02/04/2012] 